\title{
DOES SOAKING TIME DURING DISINFESTATION AFFECT GERMINATION RATES IN Dendrobium?
}

\author{
O TEMPO DE IMERSÃO DURANTE A DESINFESTAÇÃO INFLUENCIA NAS TAXAS \\ DE GERMINAÇÃO DE Dendrobium?
}

\author{
José Carlos SORGATO ${ }^{1}$; Jackeline Schultz SOARES ${ }^{1}$; Silvana de Paula Quintão SCALON ${ }^{1}$; \\ Suzana Targanski Sajovic PEREIRA ${ }^{2}$; Débora Freitas BROTTO ${ }^{3}$; Luan Marlon RIBEIRO ${ }^{1}$ \\ 1. Universidade Federal da Grande Dourados, Faculdade de Ciências Agrárias, Dourados, MS, Brasil. josesorgato@ufgd.edu.br; 2. \\ Universidade Estadual Paulista, Faculdade de Ciências Agrárias e Veterinárias, Jaboticabal, SP, Brasil; 3. Universidade Estadual de \\ Mato Grosso do Sul, Dourados, MS, Brasil.
}

\begin{abstract}
Asymbiotic germination is considered an efficient and viable technique that can increase germination rates. The effect of type and concentration of disinfestants, and the exposure time to disinfestants may differ according to the plant species. Therefore, species-specific standardization of disinfestation agent and procedure is necessary to achieve optimal germination rates. The objective of this study was to determine a disinfestation methodology to increase in vitro germination rates and the early development of seedlings of Dendrobium nobile and Dendrobium phalaenopsis, using different times for seed disinfestation and different culture media. Seeds were disinfected by soaking in a $0.8 \%$ sodium hypochlorite solution for 5 or 15 min under aseptic conditions, after which seed suspensions were either washed with water or left unwashed. Next, they were seeded in culture flasks containing four different culture media (MS, $1 / 2 \mathrm{MS}, \mathrm{K}$, and VW). The flasks were then transferred to a growth room under controlled photoperiod and temperature, where they remained under an irradiance of $20 \mu \mathrm{mol} \mathrm{m} \mathrm{m}^{-2} \mathrm{~s}^{-1}$. Germination rates of the species were evaluated 45 days after placement in the culture flasks. A higher germination rate was observed when the seeds were triple washed, regardless of the culture medium or soaking time. Seed soaking disinfestation for $5 \mathrm{~min}$ is also recommended. MS and $1 / 2 \mathrm{MS}$ media were the most effective culture media in promoting in vitro germination of the species under study.
\end{abstract}

KEYWORDS: Asymbiotic germination. Orchidaceae. Dendrobium nobile. Dendrobium phalaenopsis. Sodium hypochlorite. Ornamental species.

\section{INTRODUCTION}

The production of flowers and ornamental plants in Brazil is worth more than $\mathrm{R} \$ 7$ billion per year, with an annual growth rate between $8 \%$ and $12 \%$ that generates over 200,000 direct jobs (PAIVA et al., 2016; IBRAFLOR, 2017). Orchid cultivation is an important part of this business (JUNQUEIRA; PEETZ, 2014; 2017).

Imports of orchid seedlings in 2013 increased by about $20 \%$, compared to that in 2012 (JUNQUEIRA; PEETZ 2014). The largest exporter of Dendrobium worldwide is Thailand, while Brazil is one of the main importers (LEKAWATANA, 2010).

Given the need to supply market demand, there is a need to improve the procedures for producing flowers and ornamental plants, including orchids (PASQUAL et al., 2008; JUNQUEIRA; PEETZ, 2014; 2017). In vitro culture techniques deserve special mention among production schemes, as they are important biotechnological tools to obtain plants for both research and commercialscale production (CARDOSO, 2014).
Orchid seeds have been asymbiotically germinated since the beginning of the last century (KNUDSON, 1922). This type of seeding effectively accelerates the production of uniform orchid seedlings because it allows higher germination rates than germination under natural conditions, which depends on mycorrhizal fungi (FARIA et al., 2012; ABRÃO et al., 2014). However, although widely used, available knowledge on asymbiotic germination - particularly regarding the nutritional composition of culture media and seeding protocols to foster germination and minimize crop contamination - is still limited to a few species.

The most frequently used culture media for in vitro seeding of this botanical family are $\mathrm{K}$ (KNUDSON, 1946), VW (VACIN; WENT, 1949) and MS (MURASHIGE; SKOOG, 1962) (SILVA et al., 2015). Culture medium formulation is essential for the seed because it provides the necessary nutrients (e.g., minerals, vitamins, and growth regulators) for development of the seedling. The composition of the culture medium varies depending 
on the particular requirements of each species (FARIA et al., 2012).

The success of asymbiotic germination depends largely on the absence of microbial contamination from the culture medium. Infection of the plant material or the culture medium by fungi and bacteria can result in poor germination or poor seedling development. In their review, Silva et al. (2015) reported that ethanol (EtOH), mercury chloride $\left(\mathrm{HgCl}_{2}\right)$, and sodium hypochlorite $(\mathrm{NaClO})$ were the most commonly used products to disinfect seeds of Dendrobium under asymbiotic cultivation. Silva et al. (2015) pointed out that the type, concentration, and time of exposure to the disinfecting agent differ considerably and, therefore, require species-specific standardization.

Although seed disinfestation by sodium hypochlorite is a standard procedure, some seeds of the Orchidaceae family are susceptible to this chemical and use of this agent often results in low germination rates in an asymbiotic environment. Sodium hypochlorite can be toxic, depending on the concentration and time of exposure, thereby reducing germination rates (CHU; MUDGE, 1994).

Therefore, the objective of this study was to determine a methodology to increase in vitro germination rates and favor early development of seedlings of two orchid species (Dendrobium nobile Lindl. and Dendrobium phalaenopsis Fitzg.) using different culture media and different methods for seed disinfestation.

\section{MATERIAL AND METHODS}

Seeds were obtained from mature fruits of D. nobile and D. phalaenopsis. The plants had been manually pollinated. The orchids had been established for over eight years and were grown in a nursery covered by two overlapping 50\% shading screens, which provided an average daily photosynthetic radiation of $160 \mu \mathrm{mol} \mathrm{m} \mathrm{m}^{-2} \mathrm{~s}^{-1}$, at 22.6 $\pm 5^{\circ} \mathrm{C}$ and $73.9 \pm 10 \%$ relative humidity $(\mathrm{RH})$. The RH was maintained by micro-sprinkler irrigation.

Fruits were cut from the mature orchids with a manual pruning shear and taken to the in vitro culture laboratory at FCA/UFGD (Faculdade de Ciências Agrárias, Universidade Federal da Grande Dourados), where they were disinfested with $70 \%$ ethyl alcohol solution. Next, two fruits of each species were opened with a scalpel and the seeds were removed, homogenized, and conditioned in a desiccator with silica gel $\left(25 \pm 2^{\circ} \mathrm{C}, 75 \% \mathrm{RH}\right)$ for 14 days.

Experimental culture media treatments for seed germination included MS (MURASHIGE;
SKOOG, 1962), $1 / 2 \mathrm{MS}$ (MS at half the salt concentration), Knudson C (KNUDSON, 1946), and VW (VACIN; WENT, 1949). All three culture media were solidified with $4.0 \mathrm{~g} \mathrm{~L}^{-1}$ bacteriological

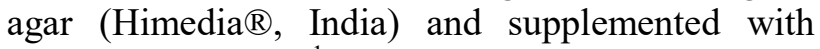
sucrose at $30 \mathrm{~g} \mathrm{~L}^{-1}$. The $\mathrm{pH}$ of the medium was measured and adjusted to 5.8 using $\mathrm{HCl}(0.1 \mathrm{M})$ if the medium was more alkaline than $\mathrm{pH} 5.8$, or $\mathrm{KOH}$ $(0.1 \mathrm{M})$ if the medium was more acidic than $\mathrm{pH} 5.8$. Prepared media were distributed among $50 \mathrm{~mL}$ polypropylene flasks (height $=5 \mathrm{~cm}$; mouth diameter $=5 \mathrm{~cm}$ ) and sealed with a screw cap. Each flask received $20 \mathrm{~mL}$ of culture medium. Next, all flasks were autoclaved at $120^{\circ} \mathrm{C}$ for $20 \mathrm{~min}$ at a pressure of 1 atm. After cooling, the flasks were transferred to a sterile environment.

Seed viability was evaluated by the tetrazolium test described by Soares et al. (2014), whereby $5 \mathrm{mg}$ seed portions were placed in test tubes containing $3 \mathrm{~mL}$ of an aqueous solution of triphenyl tetrazolium chloride $(0.5 \%)$. Seed suspensions were conditioned in a dark environment at room temperature $\left(25 \pm 2^{\circ} \mathrm{C}\right)$. After $24 \mathrm{~h}, 7 \mathrm{~mL}$ of sterile distilled water was added to the tetrazolium suspensions and stirred vigorously. A 1-mL aliquot was pipetted for identification and counting of potentially viable seeds in a Peters' chamber, using a stereoscopic binocular microscope. Seeds with dark red embryos were considered viable, whereas colorless or partially stained seeds, and embryo-free seeds were considered non-viable.

After confirming the viability of seeds, four seed samples of $5 \mathrm{mg}$ each were weighed for each species tested. The samples were taken to an aseptic environment and disinfected with $15 \mathrm{~mL}$ of $0.8 \%$ sodium hypochlorite solution. Two seed samples of each species remained immersed in the hypochlorite solution for $5 \mathrm{~min}\left(5^{\prime}\right)$ and two samples for $15 \mathrm{~min}$ (15'). Next, seed suspensions were diluted to $50 \mathrm{~mL}$ with sterile distilled water. A sample from each species and each disinfestation time was used immediately for in vitro seeding. The remaining samples underwent a triple wash with sterile distilled water (40 mL per wash). After this procedure, $50 \mathrm{~mL}$ of sterile distilled water was added to the suspensions for in vitro seeding. Using an automatic pipettor for in vitro seeding, 1,000 $\mu \mathrm{L}$ of each seed suspension was inoculated in each flask.

After inoculation, suspension cultures were transferred into a growth room and kept at $25 \pm 2{ }^{\circ} \mathrm{C}$, and a $16 \mathrm{~h}$ photoperiod under an irradiance of 20 $\mu \mathrm{mol} \mathrm{m} \mathrm{m}^{-2} \mathrm{~s}^{-1}$ provided by two $20 \mathrm{~W}$ white fluorescent lamps. Percent germination rate $(\% \mathrm{G})$ was recorded after 45 days. Propagules growing in 
the flasks were washed with $3 \mathrm{~mL}$ of sterile distilled water and packed in squared $(0.5 \times 0.5 \mathrm{~cm})$ acrylic plates $(2.0 \times 2.0 \times 0.5 \mathrm{~cm})$; non-germinated seeds (NGS) and chlorophyll propagules (CP) were counted under a stereoscopic binocular microscope. Percent germination rate $(\% \mathrm{G})$ was calculated with the following equation: $\% G=[C P /(N G S+C P)] \times$ 100. After counting, treatments were photographed using a digital camera coupled to a stereoscopic microscope, using AxionVision software version 3.1 (Zeiss $\left.{ }^{\circledR}\right)$.

The stage of development of propagule development was classified according to the stages described in Suzuki et al. (2009): stage 1 (protocorm-like body); stage 2 (seedling with first leaf formation); stage 3 (seedling with two leaves); stage 4 (seedlings with leaves and roots).

The experiment was laid out in a completely randomized design with treatments arranged in a $2 \times$ $2 \times 4$ factorial scheme (2 disinfestation times, 2 types of suspension - with or without triple washing - and 4 different culture media), with 4 replications, each consisting of one culture flask. Percent germination data were transformed $\sqrt{ }(\mathrm{x}+1)$ and then analyzed by analysis of variance. Means of disinfestation times and suspension types were compared using Student's t-test, while the means of culture media were compared using Tukey's test at a probability level of 5\%. SISVAR (Statistical Analysis Program v.5.3. Federal University of
Lavras, MG, Brazil) was used for the statistical analyses.

\section{RESULTS AND DISCUSSION}

Significant effects were observed for disinfestation time, type of seed suspension washing and culture media, and their interaction, on germination rate $(\% \mathrm{G})$ of $D$. nobile $(\mathrm{p}<0.05)$ and $D$. phalaenopsis $(\mathrm{p}<0.01)$ seeds.

Overall, seeds submitted to the triple washing procedure showed higher $\% \mathrm{G}$ than controls, irrespective of culture medium used or disinfestation time. An exception was observed in D. nobile when sown in culture medium VW and disinfested for 5', in which case no statistical difference in $\% \mathrm{G}$ was observed (Tables 1 and 2).

For $D$. nobile, 5 ' disinfestation time resulted in the highest $\% \mathrm{G}$ (overall mean of $47.1 \%$ among washing procedures), while 15 time yielded a mean $\% \mathrm{G}$ of $43.3 \%$. There was a $33.5 \%$ increase in germination rate for the 5 ' treatment upon triplewash treatment. Seeds submitted to a triple-wash showed a mean $\% \mathrm{G}$ of $63.8 \%$, while unwashed seeds showed a mean $\% \mathrm{G}$ of $30.3 \%$. The highest mean $\% \mathrm{G}$ values were recorded for $1 / 2 \mathrm{MS}$ followed by $\mathrm{K}, \mathrm{MS}$, and $\mathrm{VW}$. The highest mean $\% \mathrm{G}$ value $(81.2 \%)$ was observed for seeds soaked for $5^{\prime}$ in disinfecting solution and submitted to a triple-wash prior to sowing in $1 / 2$ MS medium (Table 1 ).

Table 1. Germination rate (\%) of Dendrobium nobile seeds according to the culture medium, type of suspension washing (TW=triple-wash; NTW=no triple-wash), and disinfestation time of seeds.

\begin{tabular}{|c|c|c|c|c|c|}
\hline \multirow[b]{2}{*}{ Washing } & \multicolumn{5}{|c|}{ Disinfestation time 5} \\
\hline & $\mathrm{MS}$ & $1 / 2 \mathrm{MS}$ & $\mathrm{K}$ & VW & Overall mean \\
\hline TW & $56.8 \mathrm{cA}^{\mathrm{a}}$ & $81.2 \mathrm{aA}^{\mathrm{a}}$ & $68.1 \mathrm{bA}^{\mathrm{a}}$ & $49.2 \mathrm{dA}^{2}$ & 63.8 \\
\hline NTW & $11.1 \mathrm{cB}^{\mathrm{b}}$ & $28.8 \mathrm{bB}^{\mathrm{b}}$ & $33.4 \mathrm{bB}^{\mathrm{a}}$ & $48.1 \mathrm{aA}^{\mathrm{a}}$ & 30.3 \\
\hline \multirow[t]{2}{*}{ Overall M } & & & & & 47.1 \\
\hline & \multicolumn{5}{|c|}{ Disinfestation time 15} \\
\hline Washing & $\mathrm{MS}$ & $1 / 2 \mathrm{MS}$ & $\mathrm{K}$ & VW & Overall mean \\
\hline TW & $45.5 \mathrm{cA}^{\mathrm{b}}$ & $72.5 \mathrm{aA}^{\mathrm{b}}$ & $56.1 \mathrm{bA}^{\mathrm{b}}$ & $53.7 \mathrm{bA}^{\mathrm{a}}$ & 56.9 \\
\hline NTW & $17.0 \mathrm{bB}^{\mathrm{a}}$ & $34.4 \mathrm{aB}^{\mathrm{a}}$ & $36.9 \mathrm{aB}^{\mathrm{a}}$ & $31.2 \mathrm{aB}^{\mathrm{b}}$ & 29.8 \\
\hline Overall M & & & & & 43.3 \\
\hline
\end{tabular}

Lowercase letters within rows compare the culture media for the same disinfestation time (5' or $\left.15^{\prime}\right)$ and type of seed suspension washing (TW or NTW) (Tukey's test, $\mathrm{p}<0.05$ ). Capital letters within rows compare the culture media for the same disinfestation time $\left(5^{\prime}\right.$ or $15^{\prime}$ ) as regards the type of seed suspension washing (Student's test, $\mathrm{p}<0.05$ ). Superscript letters within columns compare the culture medium in the same type of seed suspension washing (TW or NTW) regarding disinfestation time (Student's test, $\mathrm{p}<0.05$ ).

The 5' disinfestation time of $D$. phalaenopsis seeds resulted in the highest mean $\% \mathrm{G}$ rate among all culture media and wash treatments. There was an $82.4 \%$ increase in germination when these seeds underwent triple wash, resulting in a mean $\% \mathrm{G}$ rate of $85.5 \%$. Under these conditions,
MS and $1 / 2$ MS yielded the highest mean $\% \mathrm{G}$ values, followed by $\mathrm{VW}$ and $\mathrm{K}$. The highest mean $\% \mathrm{G}$ rate of D. phalaenopsis (95.5\%), was observed when seeds were soaked for $5^{\prime}$ in the disinfecting solution and then submitted to a triple-wash prior to sowing in either MS or $1 / 2 \mathrm{MS}$ medium (Table 2). 
Table 2. Germination rate (\%) of Dendrobium phalaenopsis seeds according to the culture medium, type of suspension washing (TW=triple-wash; NTW=no triple-wash) and disinfestation time of seeds.

\begin{tabular}{|c|c|c|c|c|c|}
\hline \multirow[b]{2}{*}{ Washing } & \multicolumn{5}{|c|}{ Disinfestation time $5^{\prime}$} \\
\hline & MS & $1 / 2 \mathrm{MS}$ & $\mathrm{K}$ & VW & Overall mean \\
\hline TW & $95.5 \mathrm{aA}^{\mathrm{a}}$ & $91.8 \mathrm{aA}^{\mathrm{a}}$ & $76.8 \mathrm{bA}^{\mathrm{a}}$ & $77.8 \mathrm{bA}^{\mathrm{a}}$ & 85.5 \\
\hline NTW & $0.6 \mathrm{bB}^{\mathrm{a}}$ & $3.3 \mathrm{bB}^{\mathrm{a}}$ & $1.6 \mathrm{bB}^{\mathrm{a}}$ & $6.7 \mathrm{aB}^{\mathrm{a}}$ & 3.1 \\
\hline \multirow[t]{2}{*}{ Overall M } & & & & & 44.1 \\
\hline & \multicolumn{5}{|c|}{ Disinfestation time 15' } \\
\hline Washing & MS & $1 / 2 \mathrm{MS}$ & $\mathrm{K}$ & VW & Overall mean \\
\hline TW & $85.2 \mathrm{aA}^{\mathrm{b}}$ & $69.8 \mathrm{bA}^{\mathrm{b}}$ & $70.9 \mathrm{bA}^{\mathrm{b}}$ & $73.5 \mathrm{bA}^{\mathrm{b}}$ & 74.9 \\
\hline NTW & $1.5 \mathrm{aB}^{\mathrm{a}}$ & $0.8 \mathrm{aB}^{\mathrm{a}}$ & $2.2 \mathrm{aB}^{\mathrm{a}}$ & $3.0 \mathrm{aB}^{\mathrm{a}}$ & 1.9 \\
\hline Overall M & & & & & 40.9 \\
\hline
\end{tabular}

Lowercase letters within rows compare the culture media at the same disinfestation time (5' or 15') and type of seed suspension washing (TW or NTW) (Tukey's test, $\mathrm{p}<0.05$ ). Capital letters within rows compare the culture media at the same time of disinfestation $\left(5^{\prime}\right.$ or $\left.15^{\prime}\right)$ in relation to the type of seed suspension washing (Student's test, $\mathrm{p}<0.05$ ). Overlapping letters within columns compare the culture medium in the same type of seed suspension washing (TW or NTW) as regards disinfestation time (Student's test, $\mathrm{p}<0.05$ ).

The MS and $1 / 2$ MS media also allowed an increase in the germination of Cattleya loddigesii Lindl., Epidendrum fulgens Brong. and Miltonia flavescens Lindl. (ABRÃO et al., 2014; VOGES et al., 2014; LEMES, 2015). However, other authors have observed that, depending on the species, media such as VW and $\mathrm{K}$ provided better germination results, as described by Dutra et al. (2009) and Suzuki et al. (2010), while studying in vitro germination of Cyrtopodium punctatum Lindl. and Cattleya bicolor Lindl., respectively.

Selection of culture medium is extremely important for successful germination of orchid seeds, since the most suitable medium for each species is directly related to the nutrients supplied to the plants (SUZUKI et al., 2009). Orchid species can be divided into two large groups, according to their basic nutritional needs (STEWART, 1989). One of the groups includes species that germinate in culture media with lower nutrient concentrations, such as $\mathrm{K}$ and VW. In contrast, the other group is composed of orchid species that germinate better in media with higher nutritional concentration, such as MS. The results presented here suggest that $D$. phalaenopsis belongs to the second group, requiring media with a broader and greater supply of nutrients, since these seeds showed the highest germination rates on MS and $1 / 2 \mathrm{MS}$ media (Figure 1). However, D. nobile belongs to the first group, which germinates better on culture media with lower nutrient concentration (Figure 1).
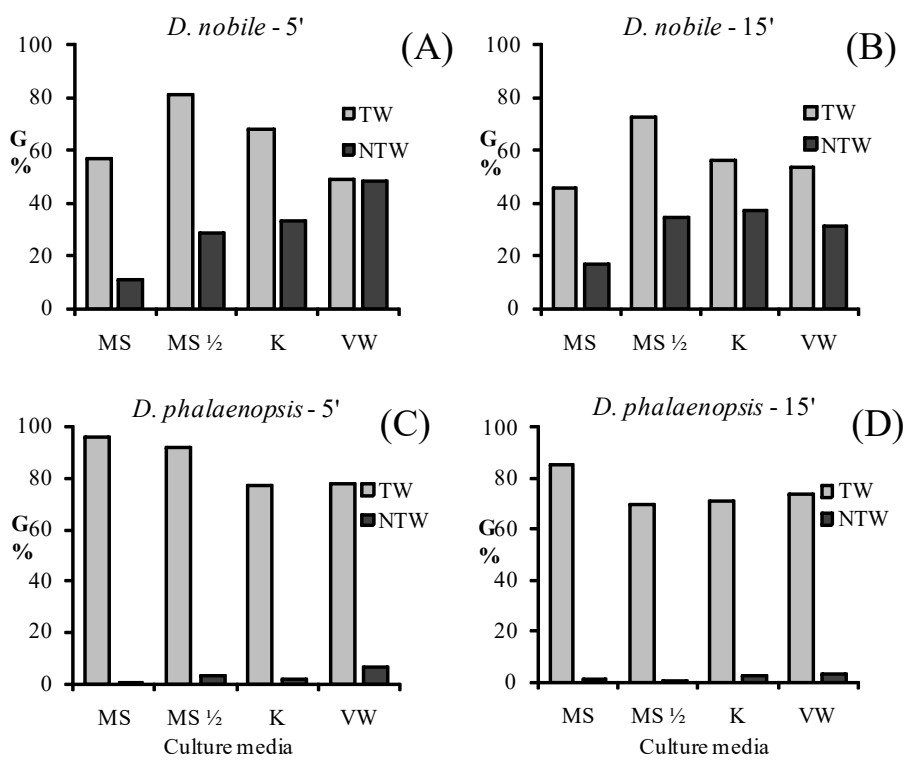

Figure 1. Percent germination rate $(\% \mathrm{G})$ of Dendrobium nobile $(\mathrm{A}$ and $\mathrm{B})$ and Dendrobium phalaenopsis $(\mathrm{C}$ and $\mathrm{D})$ seeds according to the culture medium, type of suspension washing $(\mathrm{TW}=$ with triple-wash, $\mathrm{NTW}=$ no triple-wash) and seed disinfestation time. 
In addition to the culture medium, the disinfecting agent used may also affect in vitro asymbiotic germination. The reduction in $\% \mathrm{G}$ of the seeds without the triple-wash may be related to the presence of sodium hypochlorite, which may hinder seed germination depending on the concentration used and time of exposure (CHU; MUDGE 1994). The disinfecting action of sodium hypochlorite results from the loss of $\mathrm{Cl}^{-}$, which activates the oxidation of ions that capture oxygen molecules and thus inactivates aerobic microorganisms and fungal spores responsible for most culture media contaminations (ALVAREZ-PARDO et al., 2006).

The solution $\mathrm{pH}$ is another factor that may have contributed to $\% \mathrm{G}$ reduction, since the average $\mathrm{pH}$ of the culture medium recommended for germination of orchid seeds is between 5.6 and 5.8 (FARIA et al., 2012), while the sodium hypochlorite solution used for seed disinfestation in these experiments had an alkaline $\mathrm{pH}$ (10.8), when no triple-wash was involved. Seed exposure to this high
$\mathrm{pH}$ solution, along with the high salt concentration of the media with higher nutritional contents, may have triggered chemical reactions that hindered the germination of the seeds of the species studied (Figure 1).

A reaction of ammonia and nitrate molecules with sodium hypochlorite probably occurred in the culture media with higher concentrations of ammonium and nitrate, such as MS and $1 / 2$ MS (Table 3), when seeds were not submitted to a triple-wash. The reactions that may have occurred when sodium hypochlorite reacted with ammonia and nitrate ions are presented in Equations 1,2 and 3:

$$
\begin{aligned}
& \mathrm{NH}_{4}{ }_{(\text {(aq) }}+\mathrm{H}_{2} \mathrm{O}_{(\mathrm{l})} \rightarrow \mathrm{NH}_{3(\mathrm{aq})}+\mathrm{H}_{3} \mathrm{O}^{+} \text {(aq) } \text { (Equation 1); } \\
& \mathrm{NaClO}_{(\mathrm{aq})}+\mathrm{NH}_{3(\mathrm{aq})} \rightarrow \mathrm{NaOH}_{(\mathrm{aq})}+\mathrm{NH}_{4} \mathrm{Cl}_{(\mathrm{aq})} \\
& \text { (Equation 2); } \\
& 2 \mathrm{NaClO}_{(\mathrm{aq})}+2 \mathrm{NO}_{3(\mathrm{aq})} \rightarrow 2 \mathrm{NaNO}_{3(\mathrm{aq})}+2 \mathrm{ClO}_{(\mathrm{aq})}^{-}
\end{aligned}
$$

\begin{tabular}{|c|c|c|c|c|}
\hline \multirow[t]{2}{*}{ Nutrients } & $\begin{array}{l}\text { Murashige \& Skoog } \\
\text { (MS) }\end{array}$ & $\begin{array}{l}\text { Murashige \& Skoog } \\
(1 / 2 \mathrm{MS})\end{array}$ & Knudson (K) & $\begin{array}{l}\text { Vacin \& Went } \\
\text { (VW) }\end{array}$ \\
\hline & $\mathrm{mM}$ & $\mathrm{mM}$ & $\mathrm{mM}$ & $\mathrm{mM}$ \\
\hline Ammonium $\left(\mathrm{NH}_{4}^{+}\right)$ & 20.62 & 10.31 & 3.79 & 3.79 \\
\hline Nitrate $\left(\mathrm{NO}_{3}^{-}\right)$ & 39.43 & 19.72 & 4.24 & 5.20 \\
\hline Phosphate $\left(\mathrm{PO}_{4}^{---}\right)$ & 1.25 & 0.625 & 1.84 & 2.48 \\
\hline $\operatorname{Potassium}\left(\mathrm{K}^{+}\right)$ & 20.06 & 10.03 & 1.84 & 7.04 \\
\hline Sulfate $\left(\mathrm{SO}_{4}^{--}\right)$ & 1.50 & 0.75 & 4.84 & 4.80 \\
\hline Calcium $\left(\mathrm{Ca}^{++}\right)$ & 3.01 & 1.505 & 4.24 & 0.65 \\
\hline Magnesium $\left(\mathrm{Mg}^{++}\right)$ & 1.50 & 0.75 & 1.02 & 1.02 \\
\hline Chloride $\left(\mathrm{Cl}^{-}\right)$ & 6.03 & 3.015 & - & - \\
\hline Sucrose & 87.72 & 87.72 & 87.72 & 87.72 \\
\hline Total nitrogen & 60.05 & 30.025 & 8.03 & 8.99 \\
\hline
\end{tabular}$$
\text { (Equation 3). }
$$

Table 3. Nutrient composition of the culture media used for asymbiotic germination of Dendrobium nobile and Dendrobium phalaenopsis seeds.

A high $\mathrm{pH}$ value was recorded in the first chemical reaction due to the $\mathrm{OH}^{-}$originating from the sodium hydroxide as a result of the ammoniasodium hypochlorite reaction (Equation 2), which inhibited germination. In the nitrate-sodium hypochlorite reaction (Equation 3), hypochlorite in solution dissociates as indicated by equation 4 :

$$
2 \mathrm{ClO}^{-} \rightarrow 2 \mathrm{Cl}^{-}+\mathrm{O}_{2}(\text { Equation } 4)
$$

Both $\mathrm{Cl}^{-}$and $\mathrm{O}_{2}$ are highly reactive and capable of acting directly on other molecules in the medium. $\mathrm{Cl}^{-}$and $\mathrm{O}_{2}$ act through connections to the chromophore groups and in the formation of derivative compounds with ions. In addition, oxygen oxidizes the component molecules of the medium (ATKINS; JONES 2012). Thus, the reactions described explain the low germination in the media with higher ammonium and nitrate values, when in contact with sodium hypochlorite.

Potassium concentration in MS and $1 / 2 \mathrm{MS}$ media was also high (Table 3). Considering the release of $\mathrm{Cl}^{-}$(Equation 4), there is a high likelihood that potassium will react with this anion to form 
Does soaking time...

$\mathrm{KCl}$. Potassium is a vital nutrient for plant growth and development, so a higher concentration of $\mathrm{K}^{+}$ ions is expected to provide greater germination rate, growth, and development, because it is directly linked to the synthesis of proteins, activation of several enzymatic systems involved in respiration and photosynthesis, and mechanism of cell enlargement (TAIZ; ZEIGER, 2009).

Thus, the importance of the triple-wash is highlighted. The use of this technique increased percent germination rate and resulted in more
SORGATO, J. C.

developed propagules at 45 days after placement. These propagules could be found, according to the classification described in Suzuki et al. (2009), in stage 2 (seedling with first leaf formation) and in stage 3 (seedling with two leaves). For the propagules in the no triple-wash treatment, most of the propagules were found in stage 1 (protocormlike body), some were chlorophyll deficient and several seeds did not germinate (Figure 2) after 45 days.
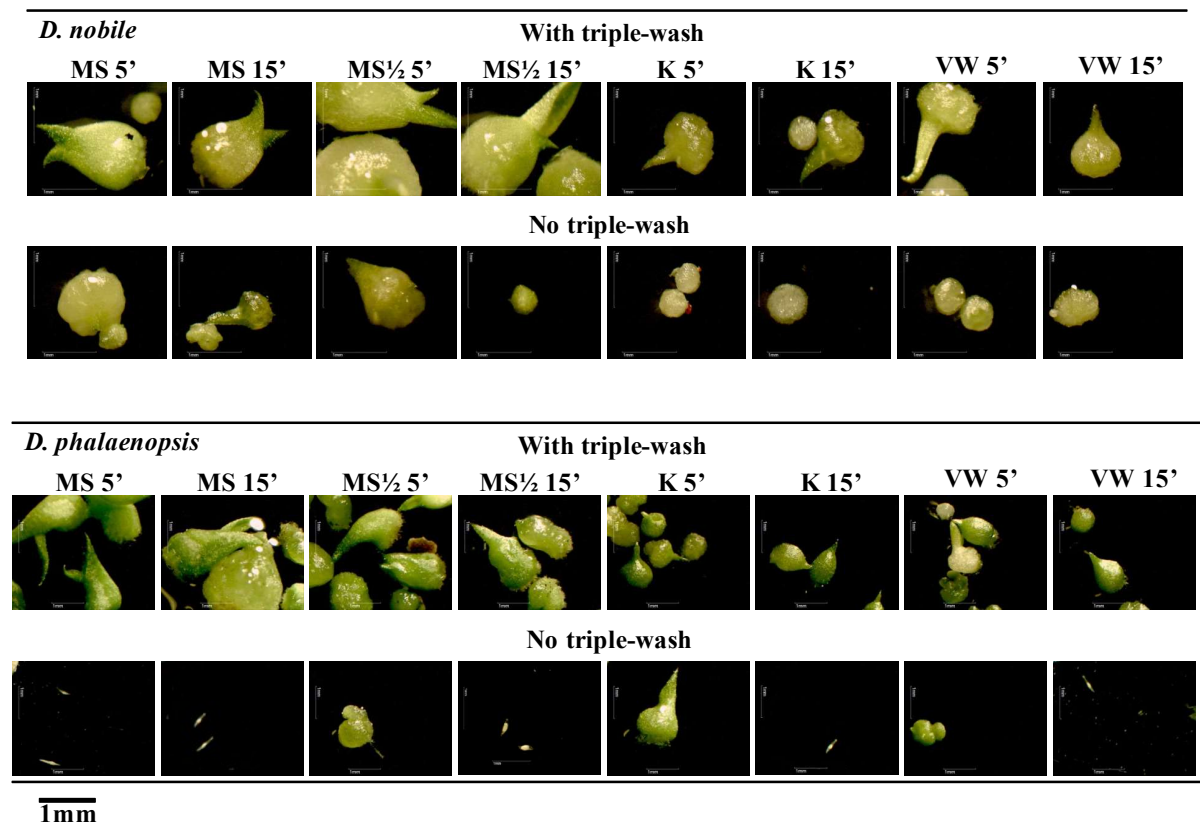

Figure 2. In vitro germination of Dendrobium nobile (A) and Dendrobium phalaenopsis (B) with triple-wash and no triple-wash at 45 days after sowing.

Disinfestation time of orchid seeds for in vitro sowing varies depending on the type and concentration of the agent used. According to Arditti and Ernst (1992), application of sodium hypochlorite solution from 5 ' to $30^{\prime}$ allows complete disinfestation of the seeds, thus solving any contamination problem. Soares et al. (2012) used sodium hypochlorite at $1.25 \%$ for $15^{\prime}$ without a triple-wash to disinfect $D$. nobile seeds and reported a $\% \mathrm{G}$ of less than $50 \%$. Similar results were observed in this study when the triple-wash procedure was not performed (Tables 1 and 2).

Faria et al. (2012) recommend using a $0.5 \%$ sodium hypochlorite solution for $15^{\prime}$. However, the results observed in this study demonstrated that disinfestation time of $D$. nobile and $D$. phalaenopsis seeds, for sowing in an asymbiotic culture medium, can be reduced to $5^{\prime}$ with the use of $0.8 \%$ sodium hypochlorite, without contamination of the culture media. This procedure increased $\% \mathrm{G}$, compared to disinfestation for $15^{\prime}$. Thus, disinfestation for $5^{\prime}$ effectively was effective for seeds of the species studied (Tables 1 and 2). Further, a significant increase in $\% \mathrm{G}$ was observed when the seeds remained for $5^{\prime}$ in sodium hypochlorite $(0.8 \%)$, followed by a triple-wash with sterilized water. These results agree with those reported by AlvarezPardo et al. (2006), who observed that disinfestation of orchid seeds required several washes with sterilized water after soaking in a sodium hypochlorite solution. The authors emphasized that this procedure is time-consuming, especially when using a large amount of seeds. However, in this study the use of a triple-wash with sterile distilled water increased $\% \mathrm{G}$ of $D$. nobile from $30.3 \%$ to $63.8 \%$, and $\% \mathrm{G}$ of $D$. phalaenopsis from $3.1 \%$ to $85.5 \%$, showing that the procedure is essential for in vitro seeding of these species. 


\section{CONCLUSION}

The 5' disinfestation time, followed by a triple-wash with sterile distilled water and sowing on $\mathrm{MS}$ or $1 / 2 \mathrm{MS}$ medium is the most effective protocol to obtain high in vitro germination rates of D. nobile and D. phalaenopsis.

\section{ACKNOWLEDGEMENTS}

The authors thank the Coordenação de Aperfeiçoamento de Pessoal de Nível Superior (CAPES) and Federal University of Grande Dourados (UFGD) for the scholarship and assistance.

RESUMO: A germinação assimbiótica é considerada uma técnica eficiente e viável resultando em elevados percentuais de germinação. Apesar do sucesso dessa técnica, o tipo, a concentração e o tempo de exposição do agente desinfestante diferem, necessitando padronização para cada espécie. Assim, a padronização do agente desinfestante e do procedimento são necessários para o aumento das taxas germinativas. Objetivou-se com este trabalho determinar metodologia que aumente a taxa de germinação in vitro e favoreça o desenvolvimento inicial de plântulas de Dendrobium nobile e Dendrobium phalaenopsis, utilizando diferentes métodos de desinfestação de sementes e diferentes meios de cultura. Sementes, sob condições assépticas, foram desinfestadas em solução de hipoclorito de sódio a $0,8 \%$, por cinco ou quinze minutos. Após esses períodos, as suspensões de sementes receberam ou não a tríplice lavagem com água. Em seguida, foram semeadas em frascos de cultivo que continham quatro diferentes meios de cultura (MS, MS $1 / 2, \mathrm{~K}$ e VW). Posteriormente, foram transferidos para sala de crescimento com fotoperíodo e temperatura controlados, onde permaneceram sob irradiância de $20 \mu \mathrm{mol} \mathrm{m}^{-2} \mathrm{~s}^{-1}$. Quarenta e cinco dias após a semeadura foi avaliada a porcentagem de germinação das espécies estudadas. Os resultados neste trabalho indicam que, independentemente do meio de cultura ou do tempo de desinfestação, as sementes quando submetidas à tríplice lavagem apresentaram porcentagem de germinação superior a àquelas que não receberam este procedimento. Recomenda-se a desinfestação das sementes por 5 minutos. Os meios MS e MS $1 / 2$ foram os mais efetivos em promover a germinação in vitro dessas espécies.

PALAVRAS-CHAVE: Germinação assimbiótica. Orchidaceae. Dendrobium nobile. Dendrobium phalaenopsis. Hipoclorito de sódio. Espécies ornamentais.

\section{REFERENCES}

ABRÃO, M. C. R.; JORGE J.; PESCADOR, R.; DE MELO, F. W.; SUZUKI, R. M. Germinação de sementes e desenvolvimento in vitro de plântulas de Cattleya loddigesii Lindl. (Orchidaceae). Revista Brasileira de

Biociências, Porto Alegre, v. 12, n. 3, p. 141-147, jul. 2014.

http://www.ufrgs.br/seerbio/ojs/index.php/rbb/article/view/2838

ALVAREZ-PARDO, V. M.; FERREIRA, A. G.; NUNES, V. F. Seed desinfestation methods for in vitro cultivation of epiphyte orchids from Southern Brazil. Horticultura Brasileira, Brasília, v. 24, n. 2, p. 217-220, jun. 2006. http://dx.doi.org/10.1590/S0102-05362006000200019

ARDITTI, J.; ERNST, R. Micropropagation of Orchids. New York: Wiley-Interscience Publication, 1992. $682 \mathrm{p}$.

ATKINS, P.; JONES, L. Princípios de química: questionando a vida moderna e o meio ambiente. 5. ed. Porto Alegre: Bookman, 2012. 1048 p.

CARDOSO, J. C. Publicação em cultivo in vitro de plantas: qualidade para o avanço científico e tecnológico. Horticultura Brasileira, Brasília, v. 32, n. 1, p. 383-384, set. 2014. http://dx.doi.org/10.1590/S0102053620140000400002 
CHU, C.; MUDGE, K. W. Effects of pre-chilling and liquid suspension culture on seed germination of the yellow Lady's slippers orchid (Cypripedium calceolus var. puvescens). Lindleyana, Florida, v. 9, p. 153159, 1994.

DUTRA, D.; KANE, M.; RICHARDSON, L. Asymbiotic seed germination and in vitro seedling development of Cyrtopodium punctatum: a propagation protocol for an endangered Florida native orchid. Plant Cell Tissue and Organ Culture, New York, v. 96, n. 3, p. 235-243, mar. 2009. http://dx.doi.org/10.1007/s11240-0089480-z

FARIA, R. T.; ASSIS, A. M.; UNEMOTO, L. K.; CARVALHO, J. F. R. P. Produção de orquídeas em laboratório. Londrina: Mecenas, 2012. 124 p.

IBRAFLOR. Instituto brasileiro de floricultura. Mercado de Flores, 2017. Disponível em: $<$ http://www.ibraflor.com/site/2017/11/04/mercado-de-flores-vera-longuini/>. Acessado em: 10 de fevereiro de 2018.

JUNQUEIRA, A. H.; PEETZ, M. S. Análise conjuntural do comércio exterior da floricultura brasileira: balanço 2013 e perspectivas para 2014. Disponível em:

$<\mathrm{http} / / /$ www.hortica.com.br/artigos/2014/2013_Comercio_Exterior_Floricultura.pdf $>$. Acessado em: $10 \mathrm{de}$ janeiro de 2017.

JUNQUEIRA, A. H.; PEETZ, M. S. Brazilian consumption of flowers and ornamental plants: habits, practices and trends. Ornamental Horticulture, Campinas, v. 23, n. 2, p. 178-184, jun. 2017.

https://doi.org/10.14295/oh.v23i2.1070

KNUDSON, L. Non-symbiotic germination of orchid seeds. Botanical Gazette, Chicago, v. 73, n. 1, p. 01-25, jan. 1922. http://www.jstor.org/stable/2470045

KNUDSON, L. A new nutrient solution for germination of orchid seeds. American Orchid Society Bulletin, West Palm Beach, v. 15, n. 1, p. 214-217. 1946.

LEKAWATANA, L. Thai Orchid: Current Situation. In: LEE, Y. I.; RUNKLE, E. (ed.) Article from $\mathbf{1}^{\mathbf{0}}$ Taiwan International Orchid Symposium. Taiwan, 2010. p. 01-11.

LEMES, C. S. R. Germinação, desenvolvimento e aclimatização de Miltonia flavescens Lindl.

(Orchidaceae). 2015. 55 f. Tese (Doutorado em produção vegetal) - Curso de Pós-Graduação em Produção vegetal, Universidade Federal da Grande Dourados, Dourados, 2015.

MURASHIGE, T.; SKOOG, F. A. A revised medium for rapid growth and bioassays with tobacco tissue culture. Physiologia Plantarum, Lund, v. 15, n. 3, p. 473-497, jul. 1962. https://doi.org/10.1111/j.13993054.1962.tb08052.x

PAIVA, P. D.; LANDGRAF, P. R. C.; JUNQUEIRA. A. H.; PEETZ, M. S.; BOLDRIN, K. V. F. Floricultura no Brasil. Revista da Associação Portuguesa de Horticultura, Lisboa, n. 121, p. 30-33, jan. 2016.

PASQUAL, M.; SANTOS, F. C.; FIGUEIREDO, M. D.; JUNQUEIRA, K. P.; REZENDE, J. D.; FERREIRA, E. A. Micropropagação do abacaxizeiro ornamental. Horticultura Brasileira, Brasília, v. 26, n. 1, p. 45-49, mar. 2008. http://www.scielo.br/pdf/hb/v26n1/a09v26n1

SILVA, J. A. T.; TSAVKELOVA, E. A.; NG, T. B.; PARTHIBHAN, S.; DOBRÁNSZKI, J.; CARDOSO, J. C.; RAO, M. V.; ZENG, S. Asymbiotic in vitro seed propagation of Dendrobium. Plant cell reports, Germany, v. 34, n. 10, p. 1685-1706, jul. 2015. http://dx.doi.org/10.1007/s00299-015-1829-2 
SOARES, J. S.; ROSA, Y. B. C. J.; SUZUKI, R. M.; SCALON, S. P. Q.; ROSA JUNIOR, E. J. Germinação assimbiótica e desenvolvimento de Dendrobium nobile Lindl. sob efeito de reguladores vegetais no tratamento pré-germinativo. Revista Brasileira Plantas Medicinais, Botucatu, v. 14, n. 4, p. 617-623, mai. 2012. http://dx.doi.org/10.1590/S1516-05722012000400007

SOARES, J. S.; ROSA, Y. B. C. J.; TATARA, M. B.; SORGATO, J. C.; LEMES, C. S. R. Identificação da viabilidade de sementes de orquídeas pelo teste de tetrazólio. Semina: Ciências Agrárias, Londrina, v. 35, n. 5, p. 2275-2284, ago. 2014. http://dx.doi.org/10.5433/1679-0359.2014v35n5p2275

STEWART, J. Orchid propagation by tissue culture techniques - past, present and future. In: PRITCHARD, H. W. Modern methods in orchid conservation: the role of physiology, ecology and management. Cambridge: University of Cambridge, 1989. Cap. 7, p. 87-101. https://doi.org/10.1017/CBO9780511551307.008

SUZUKI, R. M.; MOREIRA, V. C.; NACABASHI, M.; FERREIRA, W. M. Estudo da germinação e crescimento in vitro de Hadrolaelia tenebrosa (Rolfe) Chiron \& V.P. Castro (Orchidaceae), uma espécie da flora brasileira ameaçada de extinção. Hoehnea, São Paulo, v. 36, n. 4, p. 657-666, nov. 2009. http://dx.doi.org/10.1590/S2236-89062009000400006

SUZUKI, R. M.; ALMEIDA, V.; PESCADOR, R.; FERREIRA, W. M. Germinação e crescimento in vitro de Cattleya bicolor Lindley (Orchidaceae). Hoehnea, São Paulo, v. 37, n. 4, p.731-742, dez. 2010. http://dx.doi.org/10.1590/S2236-89062010000400004

TAIZ, L.; ZEIGER, E. Fisiologia Vegetal. 4. ed. Porto Alegre: Artmed, 2009. 820 p.

VACIN, E. F.; WENT, F. W. Some pH changes in nutrient solutions. Botanical Gazette, Chicago, v. 110, n. 4, p. 605-617, jun. 1949. https://doi.org/10.1086/335561

VOGES, J. G.; BENEVENUTO, R. F.; FRITSCHE, Y.; GUERRA, M. P. Protocorm development of Epidendrum fulgens (Orchidaceae) in response to different saline formulations and culture conditions. Acta Scientiarum. Biological Sciences, Maringá, v. 36, n. 3, p. 287-292, set. 2014. http://dx.doi.org/10.4025/actascibiolsci.v36i3.21079 